\title{
OLYMPIC CRISIS, ENVIRONMENTAL CRISIS
}

\author{
MASCARENHAS, Gilmar; ${ }^{\text {a* }}$ OLIVEIRA, Leandro Dias de ${ }^{b}$
}

(a) Phd in Geography. Professor State University of Rio de Janeiro (UERJ), Rio de Janeiro (RJ), Brazil. ORCID ID: https://orcid.org/0000-00027170-414X. CURRICULUM LATTES: http://lattes.cnpq.br/1720545300462805

(b) Phd in Geography. Professor Federal University Rural of Rio de Janeiro (UFRRJ), Seropédica (RJ), Brazil. ORCID ID: https://orcid.org/00000001-7257-0545. CURRICULUM LATTES: http://lattes.cnpq.br/5582910362793776

\section{(*) CORRESPONDING AUTHOR}

Address: UERJ, Rua São Francisco Xavier, 524 sala4006 Bl.D, CEP: 20550013, Rio de Janeiro (RJ), Brasil. Phone: (+55 21) 23340219 E-mail: gilmasc2001@yahoo.com.br

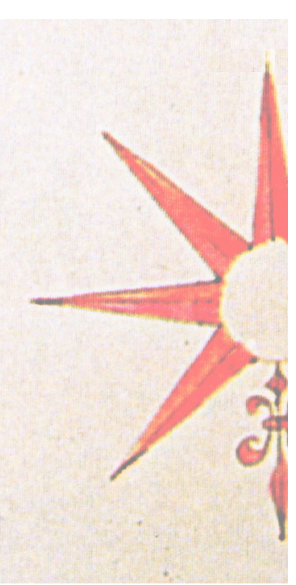

\begin{abstract}
Over the last four decades, Olympic urbanism has been constantly evolving, producing increasingly onerous large-scale urban projects with high visibility impacts on social and environmental issues in each host city. This article aims to reflect on the nature and the limits of the adoption of the concept of sustainability by contemporary Olympic projects and as a consequence understand the environmental dimension of the ongoing Olympic crisis. To this end, we will investigate: [1] the idea of sustainability from urban geography; [2] the congruencies of the Olympic crisis and the environmental crisis; and, finally, the [3] adoption of sustainability at the 2016 Summer Olympics, which took place in the city of Rio de Janeiro.
\end{abstract}

Keywords: Olympics; Environmental crisis; Sustainability.

\section{RESUMO / RESUMEN}

\section{CRISE OLÍMPICA, CRISE AMBIENTAL}

Nas últimas quatro décadas, o urbanismo olímpico evoluiu constantemente, passando a produzir projetos urbanos cada vez mais onerosos e de grande vulto, com impactos de alta visibilidade em questões sociais e ambientais em cada cidade-sede. Este artigo tem como objetivo refletir sobre a natureza e os limites da adoção do ideário da sustentabilidade nos projetos olímpicos contemporâneos e por esta via entender a dimensão ambiental da crise olímpica em curso. Para isso, investigaremos: [1] a noção de sustentabilidade a partir da geografia urbana; [2] as congruências da crise olímpica e da crise ambiental; e, por fim, a [3] adoção da sustentabilidade nos Jogos Olímpicos de Verão de 2016, que ocorreram na cidade do Rio de Janeiro.

Palavras chaves: Olimpíadas; Crise ambiental; Sustentabilidade.

\section{CRISIS OLÍMPICA, CRISIS AMBIENTAL}

En las últimas cuatro décadas, el urbanismo olímpico ha evolucionado constantemente, pasando a producir proyectos urbanos cada vez más onerosos y de gran porte, con impactos de alta visibilidad en cuestiones sociales y ambientales en cada ciudad sede. Este artículo tiene como objetivo reflexionar sobre la naturaleza y los límites de la adopción del ideario de la sostenibilidad en los proyectos olímpicos contemporáneos y por esta vía entender la dimensión ambiental de la crisis olímpica en curso. Para tal, investigaremos: [1] la noción de sostenibilidad a partir de la geografía urbana; [2] las congruencias de la crisis olímpica y de la crisis ambiental; y, finalmente, la [3] adopta de la sostenibilidad en los Juegos Olímpicos de Verano de 2016, que ronda lugar en la ciudad de Río de Janeiro.

Palabras clave: Olimpíadas; Crisis ambiental; Sostenibilidad. 


\section{INTRODUCTION}

In July 2017, for the first time in its one hundred and twenty-three-year history, the International Olympic Committee (hereinafter IOC) simultaneously selected the hosts of two consecutive Olympics. With only two candidate cities for the 2024 Summer Olympics, and with few prospects of new applications emerging for the coming years, the IOC understood that it should take an unprecedented step and anticipate the choice of the 2028 Olympic venue. Following this logic, the Committee defined that the only two candidate cities, Paris and Los Angeles, respectively, would be responsible for organizing the two editions of the event following the 2020 Tokyo Games.

This extraordinary decision reveals the concern regarding the possible embarrassment of not receiving applications for the 2028 Games, since there is evidently a crisis in the "Olympic industry". ${ }^{1}$ Over the last ten years there has been a sharp and steady reduction in the number of candidate cities for the Olympic Games, whether summer or winter. Not for the first time: in the early 1980s, the Olympic system experienced a similar process, with a sudden worldwide reduction in cities and countries interested in hosting the Games. However, that "crisis" was of much shorter duration than the current one, and in that context the central double driver of the problem was clear: the combination of the intensification of the Cold War (resulting in boycotts by the great powers and their main allies of the 1980 Moscow and 1984 Los Angeles Games respectively), as well as the breakdown of the "amateur ethos" in the Olympic system, which caused a reduction of interest by the spectating public. (GOLD \& GOLD, 2007; MIAH \& GARCÍA, 2012).

From that moment on, the irreversible collapse of the socialist bloc and the immediate permission for the participation of professional athletes greatly boosted the interest of the media and sponsors in Olympic events, rapidly "solving" the crisis. In this sense, the 1988 Seoul Games, and even more so, the 1992 Barcelona edition ratified the beginning of the glorious cycle of the commercial expansion of the event, achieving maximum monumentality and sophistication in the 2008 Beijing Games.

But this lavish model with a high local impact, both on public accounts and the environment and the quality of life of the residents of the host cities, began to provoke contrary reactions. Criticism from various sectors and social organizations, from the UN (Rapporteur on the Right to Housing) to environmental movements, neighborhood associations, leftwing parties and other activist groups, flooded the social networks and exerted some pressure on the hitherto practically unblemished global image of the Olympics.

The rhetoric of sustainability has been activated with increasing frequency in the last twenty years in order to salvage the image of the events under question and to promote a certain legitimation, despite its unsurpassed conceptual vagueness (ACSELRAD, 2004; 2009). The Sidney Games (2000) stand out as a supposed and vaunted "green" paradigm and all subsequent sporting mega-events have sought somehow (and often only rhetorically) to insert the theme of sustainable development into their projects. London (2012), for example, proclaimed itself as the first "truly sustainable games in history". The latest update of this promise is the successful Paris 2024 bid, which promises to be even "greener" than London 2012. It offers "non-polluting" public access (extending its consolidated metro system) to all the public and all the Olympic venues and promises that only $5 \%$ of the facilities will be new and definitive, greatly reducing spending and the eternal risk of ill-fated "white elephants".2

(1) This term was used by the Australian researcher Helen Lenskij to designate something beyond the "Olympic system", composed of the IOC and the various international sports confederations and federations, as well as their "sponsors" and other formally involved entities, which are only the "tip of the iceberg". This industry involves a modus operandi led by large companies (contractors, media, real estate) and state bodies that, at each event, associate themselves with the Olympic system to produce spatialities (iconic objects and the form of city, for example), sociabilities and subjectivities in full harmony with the capitalist mode of production and its colonial dimension.

(2) Available at: http://www.paris2024.org/medias/presse/paris 2024 ready to deliver the most sustainable games ever the_first_in_line_with_the_paris_climate_agreement_0.pdf. Accessed on: 04 Jan. 2018. 
As a background to the analytical exercise herein, a single question is posed: to what extent can a major sporting event contribute effectively to the expansion of environmental justice and consequently, to the construction of a sustainable city? In view of the broad and almost limitless conceptual spectrum, environmental justice is understood as basically the "environmentalization" of issues related to democracy and social inequality, aiming, through various actions, to reduce the environmental damage suffered by socially disadvantaged groups, thus promoting greater visibility and an emphasis on new "environmental conflicts" (ACSERALD, 2009).

In view of the scope and limits of the major urban projects associated with the Olympics, we intend to reflect on the role of the rhetoric on sustainable development in their formulation and, consequently, to make inferences on the environmental dimension of the ongoing Olympic crisis. To this end, we will investigate: [1] the notion of sustainability in the light of urban geography; [2] the congruencies of the Olympic crisis and the environmental crisis; and, finally, [3] the adoption of sustainability at the Rio de Janeiro Olympic Games, held between August 5 and 21, 2016.

In an attempt to reach these objectives, the following methodological procedure was organized and used: 1) the adoption of the concept of sustainability was evaluated - extracted from the diplomatic articulations on a global scale and which have a profound conceptual, economic and political malleability - in contemporary cities, especially as a discursive matrix that reverberates a type of "green city-company" utopia; 2) this is followed by various investigations regarding the general quantitative information on the Olympic candidates in the last twenty-five years to the evolution, in the same period, of the recommendations of the Olympic system about the supposed "ecological" legacy, including the global debate promoted by intellectuals and activists who question the costs and impacts of the Olympic Games, highlighting the environmental issue; 3) thirdly, there is an analysis of the Rio 2016 Project Dossier and several other documents, including the two Sustainability Management plans prepared by the organizers of the event in partnership with the municipal government of Rio de Janeiro, as well as the main actions related to the environment in the process of construction of the Olympic city.

\section{THE CONSTRUCTION OF SUSTAINABILITY AS AN ECONOMIC-ECOLOGICAL-SPATIAL PRINCIPLE}

It seems evident that sustainable development - a geopolitical and geo-economic normalization that has been consolidated worldwide since the 1980s - implies a progressive and selective economic-ecological-spatial adjustment of the current order. It thus comprises a formula of the instrumental rationality of nature, belittled as raw material, resource and fuel, and which, for this reason, presents the need for production and reproduction. Using natural resources without exhausting them, creating non-polluting technologies and producing an environmental discipline of political, economic and social management are unquestionable demands of the current spatial order.

Inserted in contemporary spatial restructuring, sustainable development is at the heart of the productive needs of this new century. The systematic adoption of the 'rational' use of nature, with the maintenance and renewal of stocks and guarantees of more judiciously used raw materials; the renovation of the technological-industrial park with ecologically correct mechanisms, through filters and other anti-pollution mechanisms; investment in alternative energy sources; the strengthening of engineering in the biological-genetic field; and the propaganda-based consolidation of environmentally sound practices, bringing different actors of civil society together on common agendas, are measures adopted omni tempore in a veritable tangle of actions incapable of breaking with the process of obliteration of nature on a global scale.

Undeniably, the concept of sustainable development goes beyond the insipid definition contained in the seminal document "Our Common Future" (issued by UNEP - United Nations Envi- 
ronment Program), indicating that it is a development model that meets "the needs of the present without compromising the ability of future generations to meet their own needs" (Brundtland, 1988, p. 46). This definition is vague, imprecise and malleable to the most diverse political and economic patterns and reverberates a global process of economic requalification of nature. Nonetheless, the term "sustainable" has progressively begun to inhabit the vocabulary of public and corporate policies and to directly influence everything from the production of ecologically certified goods to the construction of discourses about "good" environmental practices in cities.

After all, the city is, per se, an interlacing of the human and the natural, because there is nothing "purely" social or natural in the city. The city is a socio-natural hybrid full of contradictions, tensions and conflicts (SWYNGEDOUW, 2001). In this scenario, sustainability has gradually become a true discursive matrix for government interventions incorporated into urban development projects (COMPANS, 2001). The qualification "sustainable" has impinged a process of restyling of the landscape on urban restructuring, with the application of a new aesthetic and the construction of objects that, among several possibilities, have dynamized the "marketing of the city". Thus, urban sustainability has been consigned to strategies implementing the city-company metaphor by projecting on the "sustainable city" the attractiveness of investments in the context of global competition (ACSELRAD, 2009). Cities "sustentabilize" themselves without this substantially altering their social reality.

With roots in ecology, the term "sustainable" has spread as a perspective of greater social and environmental justice. In the absence of disparities between proposals and the practices or interventions in the center and in the urban periphery, the notion of sustainability has been consolidated through practical maneuvers capillarized in space.

Sustainable development was consolidated - particularly after the United Nations Conference on Environment and Development (1992), held in the city of Rio de Janeiro (OLIVEIRA, 2011) - as an important coordination mechanism between various social actors: from States on multiple scales to companies of different sizes, from social activists involved in NGOs, residents associations and unions to universities, environmental education in schools, in different sectors of education and specialized media coverage. Sustainable development, as an ideology and as a selective practice - it is notable that what is extracted from Agenda 21, pertains to direct interests, that is, what generates greater profits or is simply better advertising - has made great strides in Brazil and worldwide. Sustainability remains an anti-crisis ideological gamble, although it is emphasized that this contemporary crisis is multifaceted: [geo]political, economic, social, economic, urban and, as we shall see, Olympic!

\section{THE OLYMPIC CRISIS AND ITS ENVIRONMENTAL DIMENSION}

Since 2008, we have been living in a scenario that oscillates between recession and international economic uncertainty, a scenario that to an extent affects the predisposition of countries and cities to host costly sporting mega-events. Nevertheless, it has undoubtedly been the "anti-Olympic movement", as some prefer to call it (Lenskyy 2008, BOYKOFF, 2014), which has contributed the most to this new situation of a drastic reduction in the number of Olympic applications (which had been growing rapidly in volume since the end of the 1980s) ${ }^{3}$ as can be seen in the two graphs below, forcing the IOC to finally rethink its demands of candidate cities.

(3) It is symptomatic that only two cities have applied to host the 2022 Winter Olympics: Beijing (winner) and Almaty in Kazakhstan. 


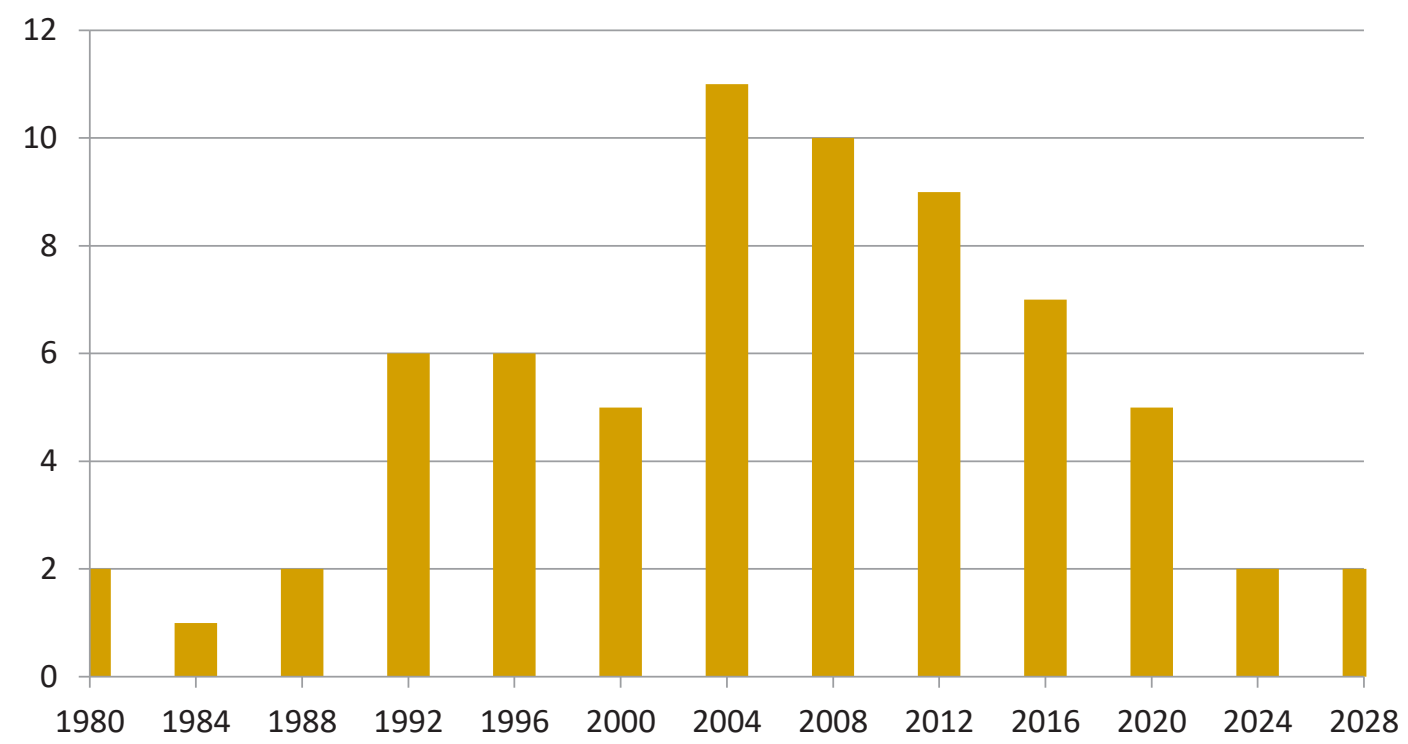

Figure 1 - Amount of candidate cities for the summer Olympic Games Source: International Olympic Committee.

In the midst of the diversity of situations in different countries, it is interesting to record a paradigmatic example. Oslo was the favorite candidate for the 2022 Winter Games. In addition to its well-known capacity for organization, its economic power and indisputable tradition in winter sports the Oslo 2022 project shone from the environmental perspective and simply presented the formidable "zero removal" index of people. After the magnificent event in Sochi 2014 (the most expensive winter sporting event in history: U\$ 51 billion) and the similar prospects for 2018, the Norwegian project suited the Olympic movement, which was concerned with reducing the wear and tear of its image. This was also the case with London 2012, which took place after two "heavy" editions (Athens 2004 and Beijing 2008), both of which had high environmental costs and disregarded human rights, Oslo would serve to ease pressures and criticisms of the Olympic system. However, the city pulled out of the race in October 2014, after extensive consultation with civil society. There is no doubt that Oslo would have been selected by the IOC if it had continued with its bid. Taking into account other withdrawals, only two cities maintained their candidacy for 2022: Beijing (with the expensive resource of abundant artificial snow) and Almaty, in Kazakhstan. Beijing was chosen and certainly presages a new wave of concerns and criticisms of the Olympic industry and its environmental impacts. At the same time, the last edition of the Winter Games, in Pyeongchang (South Korea) sparked protests from environmentalists about the destruction of tens of thousands of trees in virgin forest to build ski facilities. ${ }^{4}$

It was in this scenario of manifest crisis that the IOC's 127th Ordinary Session, held in Monaco in December 2014, approved Agenda $2020^{5}$ which, although very timid, makes some of the requirements more flexible and clearly signals possibilities of significant reductions in the costs of the event. Subsequently, at the IOC General Assembly held in August 2015 in Malaysia, it was decided to remove the elimination stages in the process of electing Olympic host cities, which we understand to be a direct expression of the disturbing finding of the aforementioned reduction in the number of applications.

Despite signaling a certain shift in values towards the flexibility and cost reduction of the Games, Agenda 2020 seems to be essentially an immediate response (more marketing than content) to the crisis scenario, including, for example, the possibility of geographically deconcentrating the sports

(4) Available at https://www.theguardian.com/environment/2015/sep/16/olympic-organisers-destroy-sacred-south-korean-forestto-create-ski-run. Accessed in: Mar.2017.

(5) Available at: http://www.olympic.org/documents/olympic_agenda_2020/olympic_agenda_2020-20-20_recommendationseng.pdf. Accessed on: March 10, 2016. 2017. 
facilities; this would allow the reduction of the impacts and costs concentrated in a single city or urban area, besides exploiting the vocations of other regions and their preexisting infrastructures.

Intending to set out strategies to recover their levels of credibility and popular support, the IOC published the new Olympic Program for the Tokyo Games in June 2017 (although the host city's preparations were already at an advanced stage), with many innovations. In the words of its president, the goal is an event that is "happier, younger, more urban" and with a better "gender balance". ${ }^{6}$ Patently trying to recapture the declining young audience, it was decided to include "urban" and "extreme" sports such as surfing, 3x3 basketball, softball and skateboarding. There is a clear pursuit of legitimacy through a discreet approach to contemporary movements and issues such as the gender debate, aimed at adopting competitions with mixed modalities (swimming, athletics, shooting, among others) to increase women's presence, combat homophobia, etc.

In this current transition process of the Olympic movement, we emphasize the declared intention to reduce the number of athletes, which in the last twenty years has remained between ten and eleven thousand in total, which is twice the average in the 1970s and triple that of the 1950s. The IOC announced a reduction of precisely 287 athletes for the Tokyo Games, corresponding to approximately $2.5 \%$ of the usual average. This measure, although timid, meets one of the main criticisms of the anti-Olympic movement: the costly gigantism achieved by the games. ${ }^{7}$ The IOC itself has reaffirmed the drastic need to make the games "financially sustainable", in an absolutely unprecedented discourse. The organizers of the 2020 Games have been warned to reduce costs "as much as possible" so that they can become an example for the future of Olympism. ${ }^{8}$ More than unprecedented, this discourse goes radically against the attitude taken by the IOC since at least the 1980s, to demand more and more investments from the host cities in luxurious facilities, as if welcoming the event meant the greatest achievement of a city aspiring to become "global". In fact, the increasing number of applications during that period favored an increase in demands by the Olympic system.

In times of suspicions about something socially canonical like "sport", the environmental agenda gradually consolidated itself as an ideological subterfuge of the Olympic Games. After all, if the gigantic urban investments under the guise of a sporting celebration began to be viewed with suspicion by the different subjects involved in the Olympic candidacies, the "environment" - and its term-guardian, "sustainability" - was the vector chosen to substantiate the belief in the financial contributions to construct the Olympic Games and to rehabilitate the hope of a true legacy in the host cities. The articulation of this ingenious and controversial movement in Rio de Janeiro's Olympic experience is discussed below.

\section{OLYMPIC SUSTAINABILITY? THE ENVIRONMENT AS AN IDEOLOGICAL RESOURCE}

Accepted as the new global prescription, the acclaimed package of principles governing the "official" utopia of sustainable development could not fail to penetrate the doors of the Olympic movement. Thus, in 1994, the International Olympic Committee signed a cooperation agreement with UNEP (United Nations Environment Program), and the following year it organized the First World Conference on Sports and the Environment in Lausanne, Switzerland. A letter of principles and commitments was established to be adopted, for example, by the future candidate cities to host the Olympics. The Environment and Sport Commission was immediately created, which establi-

(6) Alex Capstick. "Tokyo 2020: Mixed-gender events added to Olympic Games”. http://www.bbc.com/sport/olympics/40226990. Accessed on: 08 jan. 2018.

(7) Olympics 2020: three-on-three basketball among five extra sports in Tokyo. https://www.theguardian.com/sport/2017/jun/09/ ioc-announce-plans-to-make-2020-tokyo-olympics-more-youthful-urban-women. Accessed on: 08 Jan. 2018.

(8) Reducing the cost of hosting the Olympic Games. www.japantimes.co.jp/opinion/2017/07/16/editorials/reducing-cost-hostingolympic-games/. Accessed on: Dec. 2017. 
shed that the applications should provide an Environmental Impact Study for each sports facility, as well as other environmental evaluation tools, such as "recovery of damaged areas" and "reuse of facilities". In 1997, the II World Conference on Sports and Environment was held in Kuwait, which emphasized the importance of encouraging sports activities as part of the project to build a sustainable society (SCHMMIT, 2002).

Since then, the Olympic Games have come to explore environmental aspects and increasingly compete for the status of "green" or "sustainable" projects. Control of the emission of polluting gases, structures for water reuse, the use of alternative energy and several other resources available from contemporary technology, are often only included in projects, without being put into practice (KARAMICHAS, 2013). It is important to question the validity and limits of these initiatives and the degree of commitment to the environmental cause of some projects, considered paradigmatic (Sidney, 2000 and London, 2012), whose adoption of a sustainable platform only reverberates this new ecological-economic idea through spatial objects constituted by means of the structuring of the Olympic Games. In this sense, the Olympics in Rio de Janeiro in 2016 - and in a way, the soccer World Cup in Brazil (2014) - are didactic for our interpretation by establishing a series of goals and programs of "sustainability", which were unenforceable from the start.

Thus, in a moment of global fluidity, the importance of ephemeral events, but with a great ideological-territorial scope - such as a mega-conference or mega-sporting event - articulate diverse scales of action, which strategically involve the geopolitics of the choice of its headquarters, the objects and actions taken during the event and the actual fabrication of the posterior socio-spatial legacy. Thus, when we realized that practically none of the Olympic environmental commitments taken on by Rio de Janeiro in the Submission Dossier for the 2016 Olympic Games were complied with - there was no treatment of the sewage discharged into Guanabara Bay or the Jacarepaguá Lagoon, bordering the Olympic Park; nor was the Lagoa Rodrigo de Freitas opened for bathers, and not even the simple task of planting seedlings in the Atlantic Forest was concluded ${ }^{9}$ it is possible to call into question the true meaning of an Olympiad appropriate to the assumptions of sustainability.

Notably, the event tried hard to create a sustainable atmosphere. Rio de Janeiro planned for its Olympiad to be "carbon-free"; carbon emissions would be completely neutralized ${ }^{10}$ in Olympic venues. The opening ceremony of the Rio de Janeiro 2016 Olympic Games, praised globally for its plasticity and good taste, was a multicolored spectacle crowning the environmental agenda:

- The athletes received seeds to plant trees native to Brazil, ${ }^{11}$ which later revealed a scenic forest whose shrubs formed the Olympic hoops which, this time, did not have the traditional five colors, only "green";

- The symbol of ecology, created by the cartoonist Ziraldo in 1988, was designed based on the symbol of peace; the hoisting of the Brazilian and Olympic flags was carried out by 14 officers of the Environmental Police of the State of Rio de Janeiro - and not by the Army, Navy or Air Force, as customary - responsible for combating crimes against fauna and flora;

- Three giant ocas (traditional structures) were recreated with elastic patterns of Indian art;

- The impact on the soils of the global migrations was represented on the stage of the Maracanã, so that the forest was replaced by plantations and by urbanization itself;

(9) Available at: http://templates.live.com/. Accessed on: 07 Oct. 2016.

(10) Available at: http://oglobo.globo.com/economia/imoveis/sustainability-olimpica-5552201. Accessed on: 09 Sep. 2016.

(11) During the ceremony the athletes received seeds in tubes that were placed in mirrored towers, from where they would be transferred to the future "Athletes' Forest “, in the Radical Park in Deodoro. Among the seeds were Anadenanthera colubrine (Cebil), Posoqueria latifolia (Needle Flower), Wild Cacao and Spondias mombin (Yellow Mombin). However, the "Athletes' Forest" was not planted for "lack of funds" and the seedlings were taken to a farm in Silva Jardim, in the state of Rio de Janeiro. (Available in: https://globoesporte.globo.com/programas/esporte-espetacular/noticia/promessa-olimpica-floresta-dos-atletas-naofoi-planted-for-falta-de-verba.ghtml. Accessed on: 1st jun. 2018). 
- Projections of maps reproduced by NASA warned the public about the concentration of carbon dioxide on the planet;

- Finally, among many other references, the Rio 2016 Olympic Pyre was linked to a kinetic sculpture by the American Anthony Howe, representing the sun and moving in the wind therefore sources of clean energy. ${ }^{12}$ The small amount of fire, according to the organization itself, had a low-carbon flame, suggesting yet another indication that everything contributes to the desired sustainability. ${ }^{13}$

It is not a question of affirming that the sustainability of the Olympic Games in Rio de Janeiro was restricted merely to the grandiloquent opening spectacle; the construction of sustainability was selective and was used as symbolic capital in different investments:

- The Athletes Village, built by the companies Carvalho Hosken and Odebrecht Realizações Imobiliárias, with 31 buildings, 3,604 apartments and a total area of 206,000 m2, was developed according to sustainable premises: water savings of up to $40 \%$, energy reduction of $10 \%$, $10,000 \mathrm{~m} 2$ of green roofs, 75 solar collectors, to set up a water treatment plant. In addition, semi-reflective glass, eco-points, certified woods, efficient lamps, regenerative elevators, and adapted showers are references to this environmentally appropriate model; ${ }^{14}$

- The Olympic Park was also built following sustainable principles, such as selective garbage collection, the automated irrigation of gardens, with 30\% water savings, and LED lighting, to reduce energy expenditure. The park's floor - according to the Rio 2016 Committee's own sustainability manager, Tânia Braga - had qualities such as being "durable", so as not to need maintenance in the future; "reflexivity" to avoid heat islands; "permeable", where $20 \%$ of the water would be drained; and "tremor-free", for the use of wheelchairs and the elderly". Likewise, the dishes and cutlery available in the main restaurant and in the entire Olympic Village were made of natural fiber and $100 \%$ compostable $^{15}$ (See: Figure 2);

- The Olympic Tennis Center used the concept of bioclimatic architecture, with natural lighting and ventilation. Without the need for the construction of another large arena, two temporary arenas were set up next to the main arena with 5,000 seats and 3,000 seats respectively;

- The velodrome has rainwater harvesting and is the first Olympic Cycling Center in Brazil. All the wood - eucalyptus, Siberian pine, etc. - is certified to prove it is not related to environmental crimes; all the Arenas in Rio rigorously prioritized natural light and harvesting rainwater; the Olympic Stadium of Aquatic Sports and the Arena of the Future were built as dismountable structures for the reuse of structural shears, facade, roof, stairs, bathrooms, ramps and elevators; ${ }^{16}$

- Finally, the case of the Maracanã is noteworthy: the stadium - the highest sporting architectural symbol in the country - began to collect rainwater from its cover to be reused; all the electrical equipment used in the stadium is high-performance, such as air-conditioning units and mechanical pumps, thus reducing energy use, which is mainly generated by solar panels. The strategy of protecting drains and using drainage trenches and sidings was implemented to prevent impurities infiltrating the soil and air. Trees were identified and protected and environmental education courses given to employees who participated in the works; all the wood

(12) This detail can be found at: https://interactive.rio2016.com/. Accessed on: 09 Sep. 2016.

(13) Available at: http://www.cidadessustentaveis.org.br/noticias/abertura-rio-2016-leva-ao-mundo-a-mensagem-sobreoquecimento-global. Accessed on: 09 Sep. 2016.

(14) Available at: http://epoca.globo.com/Especial-Publicitario/noticia/2016/05/olimpiadas-rio-2016-um-legado-desustentabilidade-e-modernidade-.htm. Accessed on: 10 Sept. 2016.

(15) Available at: http://sustentarqui.com.br/construcao/o-parpar-olimpico-ea-sustentabilidade/. Accessed on: 10 Sept. 2016.

(16) http://sustentarqui.com.br/construcao/o-parpar-olimpico-ea-sustentabilidade/. Accessed on: 10 Sept. 2016. 
used in the modernization was certified by the Forest Stewardship Council (FSC) seal and the cement and steel used had recycled content (GOMES, 2015)

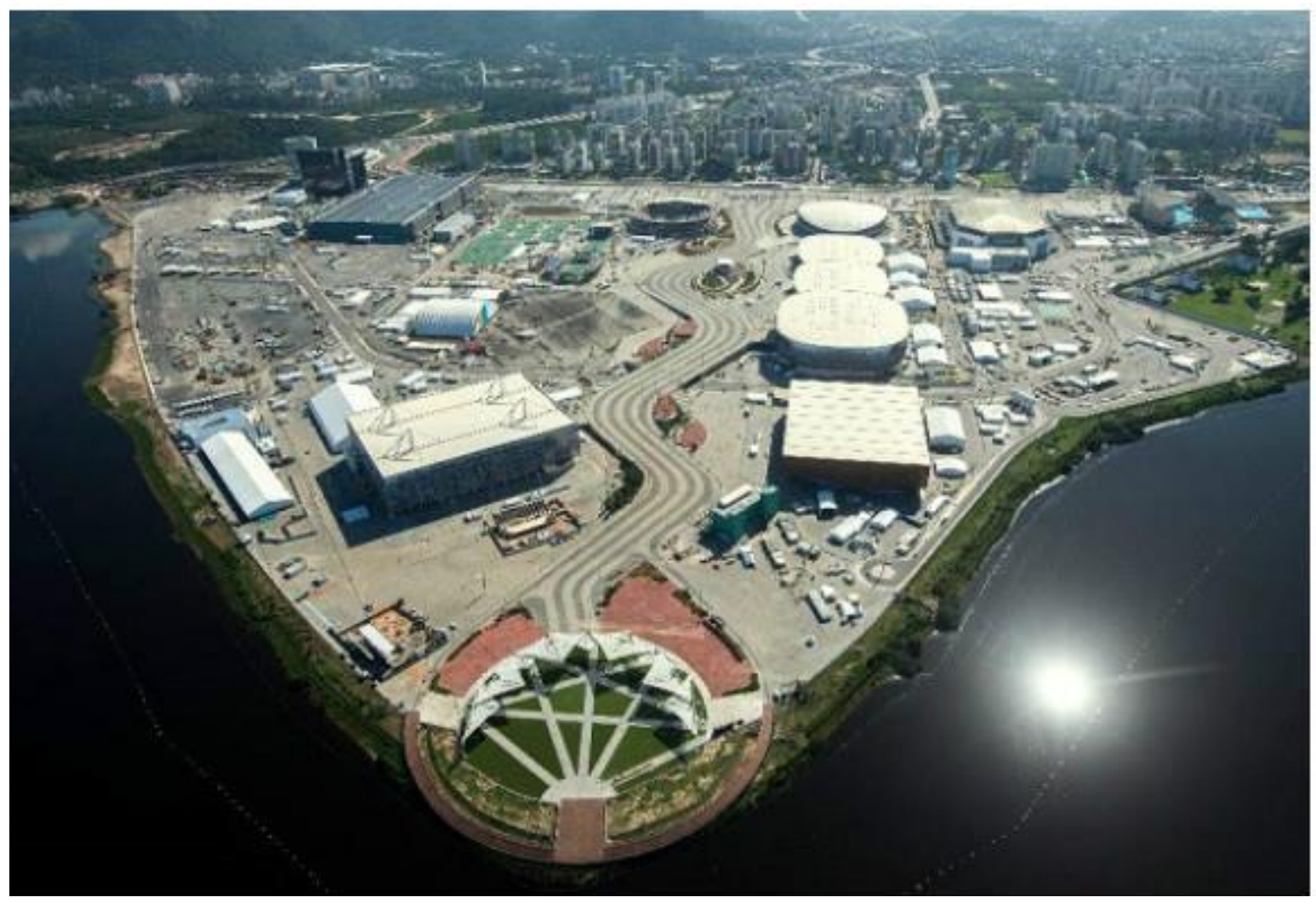

Figure 2 - The Olympic Park and its "nomadic architecture" - The shift from the planning one century ago [Agenda 21] to the ephemerality of sustainability in a compressed space-time Source: Gabriel Heusi / Heusi Action Available at: http://sustentarqui.com.br/construcao/o-parpar-olimpico-easustentabilidade/. Accessed: October 2016.

All these investments in the "ecological modernization" of the city are examples of what was intended to be incorporated as Olympic sustainability. In spite of the various removals, the price increase of urban land, the collapse of symbolic, historical and cultural ties in favor of the IOC / FIFA standardization in recent years, sustainability has been coupled with an environmental adjustment in the market. According to the Rio 2016 Games Sustainability Management Plan, "Nature is not only part of Rio de Janeiro, it is the city itself" (PGS, 2013, p. 86); In this sense, the Olympic Games have definitively shaped the city-nature under the designs of the market.

However, the main projects contained in the Rio 2016 Games Sustainability Management Plan, in the March 2013 version were the decontamination plans of the Guanabara Bay and the Lagunar System of Jacarepaguá, "Consolidating commitments taken on by the Union, the State of Rio de Janeiro and the Municipality of Rio de Janeiro to hold the 2016 Olympic and Paralympic Games" (PGS 2013, p. 41). By the Rio 2016 Games Sustainability Management Plan, in its final version published in August 2016, the decontamination of the Guanabara Bay had become the responsibility of the State Government (CEDAE - Rio de Janeiro State Water and Sewage Company, SEA - State Secretariat for the Environment), resurrecting the historic, slow and unprofitable Guanabara Bay De-pollution Program (PDBG), created in the early 1990's and its established Sewage Treatment Plants (ETE) (Penha, Ilha do Governador, Icaraí, Alegria, Sarapuí, Pavuna and São Gonçalo). There is an allusion to the acceleration of this project by the Rio 2016 Games through the implantation of the Cidade Nova Collector Trunk, which consists of the construction of a sewage collector trunk for the sewage collection of the central districts of the city of Rio de Janeiro (PGS 2016, p 72). 
The Rio 2016 Sustainability Report, entitled "Embracing Changes," announces imprecisely that "The sewage treatment index rose from 12\% in 2007 to $40 \%$ in 2013 " and that "The water quality in Guanabara Bay in the main competition areas in 2016 is within the Brazilian standards for bathing, equivalent to those adopted in the USA" (2014, p.66). This is not just the fictionalization of reality per se, even with the Olympic alibi it is a certainty that not even the half of the initially proposed goal was reached: Guanabara Bay, even with "eco-barriers" and "eco-boats", remains inhospitable, polluted and environmentally unsustainable (MASCARENHAS, OLIVEIRA, PONTES, 2016). It continues to receive, without treatment, almost half of the 461.5 million liters of domestic sewage produced daily by the surrounding municipalities, equivalent to 185 Olympic-sized swimming pools. ${ }^{17}$ No less than $75 \%$ of the bay's margins are degraded by untreated sewage and all types of waste, around 18,000 liters of untreated sewage per second and 200 tonnes of waste per day. ${ }^{18}$ (See Figure 3).

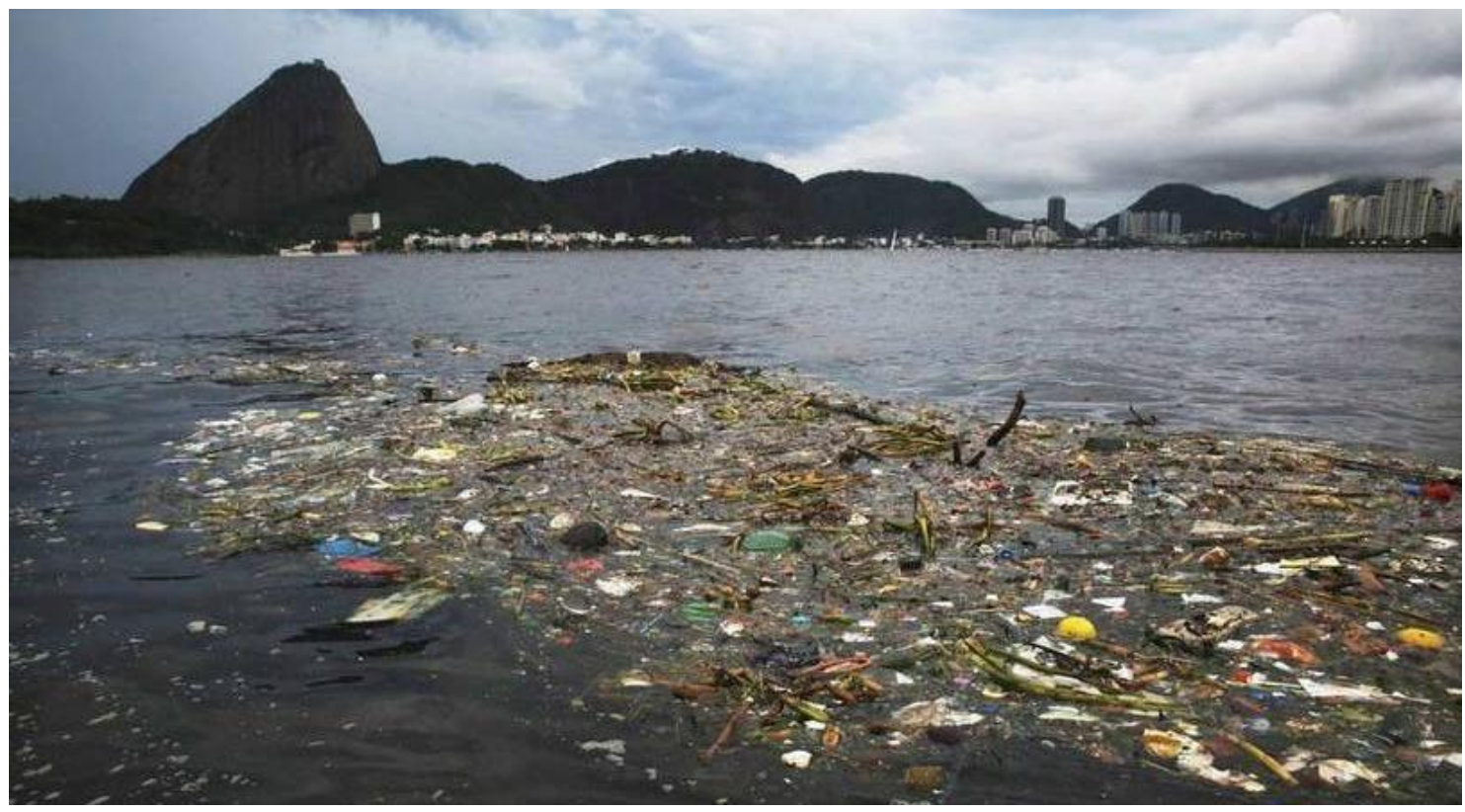

Figure 3 - "The Rio 2016 Games condemned to live with pollution", according to RTP (Radio and Television of Portugal). Is there indeed an Olympic environmental legacy?

Available at: http://www.rtp.pt/noticias/Jogos-olimpicos-2016/baia-de-guanabara-poluida-recebe-provas-de-vela d936351. Accessed on: 09 Oct. 2016.

In addition to Guanabara Bay, the environmental recovery of the Jacarepaguá Lagunar Complex aimed to desilt the Jacarepaguá, Camorim, Tijuca and Marapendi lagoons, expand the Joatinga canal and recover the mangrove swamps surrounding the lagoons. With interventions by the Public Prosecution Service and government disinvestments (PGS, 2016, p.74), another possible environmental legacy did not go beyond the letter of intent. ${ }^{19}$

It is evident that in the Rio 2016 experience, environmental concern was shifted to a secondary level in the process of building the Olympic city, functioning primarily as a necessary rhetoric legitimating high spending and impacts. It was therefore limited to what Acselrad (2009, p. 24) calls the

(17) https:/extra.globo.com/noticias/rio/esgoto-depejado-todo-dia-na-baia-de-guanabara-encheria-185-piscinasolimpicas-17193820.html. Accessed on: 10 May. 2017.

(18) To see: http://www.estrategiaods.org.br/olimpiadas-2016-the-ambiental-on-easy-priority-interview-pecial-with-mariomoscatelli/. Accessed on: 10 May. 2017

(19) Alongside the failed decontamination project in Guanabara Bay, considered the main environmental promise of the Rio 2016 Games legacy (MASCARENHAS et al., 2017), the destruction of a significant part of a protected natural area for the construction of the Golf Course exposes the strict limits of implementation of Environmental Justice policies in the context of the neoliberal Olympic city. This Course was built in a full environmental protection area, suppressing almost 60,000 square meters of the Marapendi Reserve. The project involved explicit private interests of the real estate sector, with the construction of a luxury residential development favored by sudden alteration of the urban norms for the location. 
"ecological modernization of cities", due to the emphasis on technological adaptations to produce ecological "showcases", glittering objects embedded in the polluted metropolis and lacking basic sanitation. The VLT (Light Rail Vehicle), installed in the central area of the city, despite its intrinsic qualities (such as its role in the important reduction of toxic gas emissions), crosses unhealthy and abandoned sections of the Port Zone, generating a radical contrast in the urban landscape. In addition, this "sustainable" modality of urban mobility represents a tiny fraction in a metropolis dominated by motorized and polluting transport (BRAATHEN et al., 2014).

\section{FINAL CONSIDERATIONS}

In the eyes of the Olympic movement itself there is a worrying scenario of crisis. This crisis is fundamentally expressed in the sharp reduction of cities and countries interested in hosting a formerly hotly disputed event. During the cycle of high demand, between the mid-1980s and the end of the first decade of this century, the IOC took advantage of the favorable situation to expand the number and level of requirements for postulant cities. These, in turn, seeking success in fierce disputes (there was a record of eleven official candidacies for the 2004 Games), produced more and more audacious projects. In this process, there was a global emergence of a new urbanism, based on urban marketing, state partnership with large companies and impactful operations, according to the well-known global and competitive city prescription (HOLZ, 2011; HORNE \& WHANNEL, 2012). The result of this process was, as we have seen, the creation of a model of monumental and extremely expensive Olympic urbanism.

However, in the eyes of the ecological movement and other social activists, and according to the analysis of several scholars, the crisis that has been established in the last ten years lies in other dimensions of the real and not the mere global disinterest in the organization of these events. It concerns the increasing volume of public spending and the direction towards the construction of sophisticated architectural icons and sports facilities of uncertain future use, as well as in heteronomous decision-making processes, most of which clearly violate human rights and whose authoritarianism benefited a few private groups at the expense of the collective interest.

At the same time that Olympic urbanism was growing, the idea of sustainability was growing globally, with the Rio 92 Conference as a significant milestone. The IOC, like other large global corporations, would not delay in adopting the environmental discourse, still in the course of that decade, as we have emphasized herein. However, since the Olympic industry constituted a broad coalition of private interests, with the addition of the aforementioned megalomaniac urban projects to join other major interests on the local scale (contractors, landowners and large real estate capital), Olympic urbanism was adopting, progressively and paradoxically, aggressive characteristics towards the environment.

Thus, the way in which the Olympic system was able to adopt the idea of sustainability was merely limited to rhetoric (of the many unfulfilled promises) and, in many cases, to the mere "ecological modernization" of the installations, a procedure that provides reactions of admiration for the innovative and futuristic nature of the technologies used, but that are of a very limited scope, in no way altering the broader scenario of the environmental quality of the cities.

In recent years, owing to the pressures of civil society, the IOC has admitted the crisis of its wasteful model and has triggered not only the creation of a new regulatory apparatus (Agenda 2020) but also radically altered its discourse. Shortly before the 2016 Games, which we consider to be the last edition of a monumental and lavish cycle, the Olympic system already warned the local organizing committee to establish a consistent plan for the subsequent use of "useless" or little-used facilities. The size of the popular demonstrations of June 2013 were obvious to the world, part of them directed at the excessive expense of the games (including the 2014 World Cup) and their exclusionary character. Thus, in Rio de Janeiro, two sustainability plans for the Olympic city 
were produced, but with world-renowned derisory practical effects. As a result, from 2016, the adoption of a more radical discourse within the Olympic system has been evident, encouraging the next Olympic host city to reduce spending to the maximum extent possible. In other words, it announces the end of the "red carpet" for the "lords of the rings".

The IOC understands perfectly well that the reduction of the monumentality of the Olympic Games will affect local private interests, especially contractors, landowners and real estate agents, but not the profits of the Olympic system. These derive mainly from the technical-scientific-informational environment and not from the actions on urban materiality: advertising contracts, commercialization (in the millions of dollars) of television broadcasting rights and revenues from sponsors. Therefore, the new measures are intended primarily to ensure the "good image" of Olympism, severely eroded by the avalanche of criticism on a global scale, and thus maintain the high profits of the IOC. The environmental discourse proved insufficient to guarantee such an image in the face of mass dissemination of white elephants, mainly through social networks, as well as the echoing protests of dozens (Rio 2016 case) or hundreds (in Beijing 2008) of thousands of people removed to peripheries distant from celebrated "Olympic" cities (BROUDEHOUX, 2007). Therefore, the Olympic crisis as perceived by the IOC will try to be (and probably will be) circumvented by re-dimensioning the size of the events and also by the urgent alteration of the Olympic program, inserting a "cheerful, jovial, urban and less macho package". ${ }^{20}$

Certainly, it is not directly in the interest of the Olympic system to build facilities that have a worldwide repercussion as an "environmental disaster." Recently, these problems have been recurrent, but they seem to form a kind of tacit agreement between host cities and the Olympic system: by undertaking astronomical expenditures to host the event, they promote the recognition and appreciation of Olympism, but, on the other hand, are "licensed", to some extent, to promote operations in which private interests surpass the most elementary environmental principles in the name of profit. Such was the aforementioned case of the Olympic Golf Course in Rio de Janeiro. ${ }^{21}$

The IOC, supposedly, realizes that the true planetary "environmental crisis" cannot be resolved within the framework of the capitalist system, since the (rapid) time of capital rotation (its reproduction) with its growing technological apparatus is not in line with the slow pace of nature. It must also realize the extent to which large cities, the preferential, if not exclusive, stage for modern Olympic events, have become privileged spaces for capitalist accumulation. In this sense, it is difficult to escape the mechanisms and interests that involve the production of urban space, easily absorbed by city projects in mega-sporting events. It remains for the Olympic system to reproduce the dominant strategy of resorting to sustainable development as rhetoric and publicity.

Some scholars worried about the high costs and socio-environmental impacts of Olympic urbanism have already suggested the end of the current mobile system, through the creation of a single and definitive Olympic park. Recently, US geographer John Rennie Short proposed the construction of a site to be funded by the IOC on one of the Greek islands, thus returning to the historical cradle of Olympism, practiced there for eight hundred years. In fact, the first edition of the modern era of the Games was held in Athens in 1896. At the time, the Greek monarchy suggested that the park be built as the permanent venue for the event, which was rejected by the Baron de Cobertin under the consistent allegation of the need to better disseminate the "Olympic movement", but as Short (2015) states, this need no longer exists. What remains is the very compromising wake of the event.

(20) Available at: https://www.olympic.org/news/tokyo-2020-event-programme-to-see-major-boost-for-female-participationyouth-and-urban-appeal. Accessed on: Jan. 12, 2018.

(21) At the Winter Olympics, South Korea - 2018, organizers promised that Pyeongchang would deliver the "Green Dream" Olympics with the most advanced environmental strategies. Then they cut down 58,000 trees in a 500-year-old sacred forest on Mount Gariwang to clear the way for a ski run. The South Korean Forest Service had declared this protected area a Forest Conservation Area, but this designation was suspended. Officials said the forest could be restored after the Games, but experts said it would be impossible. Once again, The "green dream" did not materialize (see: "At the Pyeongchang Olympics, there's a chasm between glitzy spectacle and grimy reality “, available at: http://www.latimes.com/opinion/op-ed/la-oe-zirin-boykoffpyeonchang-olympics-20180208-story.html. Accessed on: Feb. 2018). 
The alliance of the Olympic industry with major economic interests and, above all, the current way of "making a city" makes it much more difficult to adopt the abovementioned proposal. Still, we believe in the ongoing transition to a model of Olympic urbanism less committed to such interests. The 2020 agenda and the advent of a new IOC stance, discussed here, tend to minimize the environmental impacts of each event. Far short of contributing to solving the global environmental crisis and the search for environmental justice, but certainly with a lower rate of aggression to ecosystems and the quality of urban life, especially those segments most vulnerable to the mechanisms of despoliation.

\section{BIBLIOGRAPHIC REFERENCE}

ACSELRAD, Henri (Org.). Justiça ambiental e cidadania. Rio de Janeiro: Relume Dumará, 2004.

ACSELRAD, Henri (Org.). A duração das cidades. Rio de Janeiro: Lamparina, 2009.

ACSELRAD, Henri. Discursos da Sustentabilidade Urbana. Revista Brasileira de Estudos Urbanos e Regionais (1): 79-90, 1999. Acesso em: 25 de febrero de 2018. Disponível em: http://www.redalyc.org/ articulo.oa?id=513952491010 . Acesso em: 20 de fevereiro de 2018.

BOYKOFF, J.Activism and the Olympics. New Jersey/London: Rutgers University Press, 2014.

BRAATHEN, E.; SORBOE, C. M.; MASCARENHAS, G. . BRICS, mega-sport events and Rio de Janeiro as a city of exception. Tensões Mundiais / World Tensions, v. 10, p. 348-362, 2014.

BROUDEHOUX, Anne-Marie. Spectacular Beijing: the Conspicuous Construction of an Olympic Metropolis. Journal of Urban Affairs, 29 (4), pp. 383-399, sep. 2007.

COMPANS, Rose. Cidades sustentáveis, cidades globais: antagonismo ou complementaridade. In: ASCELRAD, Henry (Org.). A duração das cidades. Rio de Janeiro, DP\&A, 2001.

GOLD, J., GOLD, M. Olympic Cities. London \& New York, Routledge, 2007.

GOMES, Victor Arouca. Maracanã sustentável: um estudo sobre a questão ambiental nos megaeventos esportivos. Espaço e Economia: Revista Brasileira de Geografia Econômica, Ano 4, Número 7, Jul./ Dez. de 2015.

HOLZ, J-M. (org.) Les Jeux olympiques et leurs territories. Perpignan: Press Universitaires de Perpignan, 2011.

HORNE, John \& WHANNEL, Garry. Understand the Olympics. New York: Routledge, 2012.

LENSKYJ, H. Olympic industry resistance. New York: State University of N. York Press, 2008.

LENSKYJ, H. Inside the Olympic Industry. Albany: State University of New York Press, 2000.

MIAH, A. e GARCÍA, B. The Olympics. London and New York, Routledge, 2012.

MASCARENHAS, Gilmar; OLIVEIRA, Leandro Dias de; PONTES, Jeferson. Alexandre Pereira. A Baía de Guanabara não é um Tema Olímpico. Continentes, v. 10, p. 69-86, 2017.

OLIVEIRA, Leandro Dias de. A Geopolítica do Desenvolvimento Sustentável: um estudo sobre a Conferência do Rio de Janeiro (Rio-92), 2011. 283 p. Tese (Doutorado em Geografia) - Instituto de Geociências, Universidade Estadual de Campinas (UNICAMP), Campinas - SP, 2011.

SCHMITT, P. O Movimento Olímpico e o Meio Ambiente. In: DACOSTA, Lamartine; MIRANDA, Renato; TAVARES, Otávio. Esporte, Olimpismo e Meio Ambiente. Rio de Janeiro: Editora Gama Filho, 2002. Disponível em: http://www.intaead.com.br/ebooks1/livros/ed\%20fisica/01.\%20Esporte\%20Olimpico.pdf. Acesso em: 05 de março de 2016.

SHORT, J. R. Globalization, cities and the Summer Olympics. City, 12(3), 321-340, 2008

SHORT, J. R. We should host the Olympics in the same place every time. Washington Post (july, 28, 2015). Disponível em: https:/www.washingtonpost.com/posteverything/wp/2015/07/28/we-should-host-the-olympics-in-the-same-place-every-time/ Acesso em: 10 de fevereiro de 2018.

SWYNGEDOUW, Erik. A cidade como um híbrido: natureza, sociedade e "urbanização-cyborg”. In: ACSELRAD, Henri (org.). A duração das cidades. Rio de Janeiro: D, P \& A, 2001. 


\section{DOCUMENTS CONSULTED:}

EMBRACING CHANGES: Rio 2016 Sustainability Report, September 2014.

Available at: https://www.rio2016.com/sites/default/files/parceiros/relatoriodesustentabilidade_rio2016_ set2014.pdf. Accessed on: 09 Oct. 2016.

BRUNDTLAND, Gro Harlem. WORLD COMMISSION ON ENVIRONMENT AND DEVELOPMENT 1988. Our Common Future (Brundtland Report). Rio de Janeiro: Fundação Getúlio Vargas, 1988.

DOSSIER of Rio de Janeiro candidacy to host the 2016-1 Olympic and Paralympic Games. Rio 2016 - Candidate City. Available at: https://www.rio2016.com/sites/default/files/parceiros/dossie_de_candidatura_v1.pdf . Accessed on: 09 Oct. 2016.

OLYMPIC AGENDA 2020 Context and Background. International Olympic Committee, 09 December 2014. Available at: https://stillmed.olympic.org/media/Document\%20Library/OlympicOrg/Documents/Olympic-Agenda-2020/Olympic-Agenda-2020-Context-and-Background.pdf. Accessed on: March 10, 2016. 2015. OLYMPIC AGENDA 2020 20+20 Recommendations. International Olympic Committee, 09 December 2014. Available at: https://stillmed.olympic.org/media/Document\%20Library/OlympicOrg/Documents/Olympic-Agenda-2020/Olympic-Agenda-2020-20-20-Recommendations.pdf. Accessed on: March 10, 2016. 2015. PGS, 2013 - Rio 2016 Games Sustainability Management Plan (March 2013, version 1). Available at: https://www.rio2016.com/sites/default/files/parceiros/plano_gestao_sustentabilidade_ago2013.pdf Accessed: October 2016.

PGS, 2016 - Rio 2016 Games Sustainability Management Plan - Sustainability Strategies (Final Version), July 1, 2016, Rio de Janeiro, RJ. Available at: http://www.brasil2016.gov.br/en/noticias/conheca-o-plano-de-gestao-de-sustainability-of-jogos-rio-2016/08032016_plano_sustentabilidade.pdf. Accessed on: 09 Oct. 2016.

\section{PAGES ELECTRONICS CONSULTED:}

Opening Rio 2016 takes a message on global warming to the world, available at: http://www.cidadessustentaveis.org.br/noticias/abertura-rio-2016-leva-ao-mundo-a-mensagem-sobre-oquecimento-global. Accessed on: 09 Sep. 2016.

ALEXO, Mario. Polluted Guanabara Bay receives sailing competition, available at:

http://www.rtp.pt/noticias/Jogos-olimpicos-2016/baia-de-guanabara-poluida-recebe-provas-de-vela d936351. Accessed on: 09 Oct. 2016.

KNOWLEDGE, Miguel. IOC president Paes rebuts on golf course: 'The mayor pressed hard for the construction of this course' said Thomas Bach, available at: https://oglobo.globo.com/esportes/presidente-do-coi-rebate-paes-sobre-campo-de-golfe-15436353. Accessed on: 8 Aug. 2017.

CAPSTICK, Alex. Tokyo 2020: Mixed-gender events added to Olympic Games, available at: http://www. bbc.com/sport/olympics/40226990. Accessed on: 8 Jan. 2018.

FARINA, Carolina. Temer is booed at the opening of the Rio 2016 Games, available at: http://veja.abril. com.br/brasil/temer-e-vamiado-ao-abrir-os-jogos-rio-2016/. Accessed on: 09 Oct. 2016.

https://s01.video.glbimg.com/x720/5215616.jpg. Accessed: October 2016.

http://www.apo.gov.br/wp-content/uploads/2016/05/abril2016-960x600.jpg. Accessed on Oct 09. 2016.

Paris 2024 Olympic Games, available at: http://www.paris2024.org/medias/presse/paris_2024_ready_to_ deliver_the_most_sustainable_games_ever_the_first_in_line_with_the_paris_climate_agreement_0.pdf. Accessed on: 04 Jan. 2018.

MERGULÃO, Alfredo; CLAVERY, Elisa. Sewage dumped every day in Guanabara Bay would fill 185 Olympic-size swimming pools, available at: https:/extra.globo.com/noticias/rio/esgoto-depejado-todo-dia-na-baia-de-guanabara-encheria-185-piscinas-olimpicas-17193820.html. Accessed on: 10 May. 2017. 